\title{
The structure, morphometry and vascular perfusion of the testis in the rufous sengi (Elephantulus rufescens)
}

\author{
KISIPAN, M. L., ODUOR-OKELO, D., MAKANYA, A. N. and ONYANGO, D. W. * \\ Department of Veterinary Anatomy and Physiology, University of Nairobi, Chiromo Campus, off Riverside drive, \\ Nairobi, Kenya, P.O. Box 30197 - 00100 \\ *E-mail: dwo@uonbi.ac.ke
}

\begin{abstract}
Introduction and Materials and Methods: Sengis are testicondid, monogamous afrotherian mammals. The testes, pattern of testicular blood vessels and anatomical disposition of caudal vena cava were examined macroscopically in the rufous sengi (Elephantulus rufescens). Testicular structure was further studied microscopically and its components quantified using stereology. Results: The testes were cylindrical in shape and located caudolateral to the kidneys. The testicular arteries branched from renal arteries, ran to the respective testicles without close association with other vessels, while the veins ran straight to the caudal vena cava without pampiniform plexus or intimate association with cognate arteries. There were two caudal vena cavae that united after receiving the renal veins. The seminiferous tubules were bound by a peritubular boundary tissue with a single layer of myoid cells while the interstitial tissue had polyhedral or elongate Leydig cells and connective tissue elements. The testicular volume was estimated at $0.089 \pm 0.0031 \mathrm{~cm}^{3}$ with the seminiferous tubules (mean diameter $=210 \pm 5.7 \mu \mathrm{m}$ ) constituting $89.4 \pm 0.8 \%$ of its volume and tubulosomatic index of $0.38 \%$. The interstitial tissue and tunica albuginea constituted $8.9 \pm 0.81 \%$ and $1.7 \pm 0.1 \%$ of the testis volume respectively. Conclusion: The testis exhibited general mammalian features while its vascular pattern was simple without indications of a role in testicular thermoregulation as is the case for other afrotherians. The investment of body mass in seminiferous tubules suggests a spermatogenic activity higher than expected in monogamous animals. The double caudal vena cava could be a result of retention of the left supracardinal vein to adulthood.
\end{abstract}

Keywords: sengi, testis, morphology, morphometry, vessels.

\section{Introduction}

Sengis, also known as elephant shrews, are small monogamous, mainly insectivorous mammals endemic to Africa that constitute the order Macroscelidea (NOWAK, 1999; KINGDON, 2001). Based mainly on molecular techniques, these animals have been grouped together with other indigenous African mammals belonging to different orders, in a super ordinal clade called afrotheria (SPRINGER, CLEVEN, MADSEN et al., 1997; VAN DIJK, MADSEN, CATZEFLIS et al., 2001; ARNASON, ADEGOKE, BODIN et al., 2002).

The mammalian male gonads are paired organs whose location shows variations between various groups. They develop in the abdomen then descend, in a majority of mammals, to either the scrotum or an intermediate position between the original abdominal and scrotal positions. Based on the extent of descent (or lack of it), eutherian testis can be described as being testicondid, descended ascrotal or descended scrotal (WERDELIN and NILSONNE, 1999; KLEISNER, IVELL and FLEGR, 2010). Afrotherians are primary testicondid mammals, with the testes located just caudal to the kidneys (STOCH, 1954; SHORT, MANN and HAY, 1967; GLOVER and SALE, 1968; WOODALL, 1995).

The testes are supplied by testicular arteries which generally arise from the abdominal aorta and then exit from the abdominal cavity through the inguinal canal to reach the respective testis via the spermatic cord (SETCHEL and BREED, 2006). The testicular vein, on the other hand, exits from the testis and then retraces the course of the artery to drain into the caudal vena cava (DYCE, SACK and WENSING, 2002; ROMMEL, PABST, McLELLAN et al., $1991,1994)$. In some species, the left testicular vein drain into the left renal vein (BUDRAS, McCARTHY, FRICKE et al., 2007). Along the spermatic cord of scrotal mammals, the testicular vein forms a network, the pampiniform plexus, which is intimately associated with the highly convoluted testicular artery (DYCE, SACK and WENSING, 2002; BUDRAS, McCARTHY, FRICKE et al., 2007).

The mammalian caudal vena cava is generally a single large median vein which begins caudally after the union of the two common iliac veins then extends cranially up to the right atrium, receiving all the veins draining the pelvic and abdominal viscera; kidneys and gonads included (DYCE, SACK and WENSING, 2002; MOORE and PERSAUD, 2003). It arises from three paired primordial veins; the postcardinal, sub-cardinal and supra-cardinal veins which develop in succession. These veins undergo a series of changes that include interconnections and degeneration of different segments and, later, incorporation of the right hepatic vein (proximal segment of the right vitelline vein) to form the definitive caudal vena cava (MOORE and PERSAUD, 2003).

The mammalian testis is bound by tunica albuginea and its parenchyma generally comprises a predominance of seminiferous tubules interspersed with narrow rims of interstitial tissue (EURELL and FRAPPIER, 2006). In some 
species, however, the parenchyma is largely predominated by interstitial tissue (FAWCETT, NEAVES, and FLORES, 1973; ONYANGO, ODUOR-OKELO and OTIANG'A-OWITI, 1993; LEAL, BECKE-SILVA, CHIARINI-GARCIA et al., 2004). Seminiferous tubules form the spermatogenic tissue of the testis, therefore, its quantitative parameters could be of great importance as indicators of spermatogenic capacity (CALDEIRA, PAULA, MATTA et al., 2010; MELO, SOUSA, COSTA et al., 2013). In the sengi, information regarding the ultrastructure, quantitative distribution of the components of testicular parenchyma and the various parameters of the seminiferous tubule indicative of spermatogenic activity are generally absent.

The present study aims at providing information on the structure (histological and ultrastructural) and morphometry of the testis in the rufous sengi hitherto unknown, with particular focus to the various seminiferous tubule parameters. The arrangement of testicular vessels and the caudal vena cava was also highlighted and discussed.

\section{Materials and Methods}

\subsection{Animal handling and macroscopic examination}

Ten (10) adult male rufous sengis trapped from the areas around Voi town, approximately 350 kilometres south-east of Nairobi, Kenya, were used in this study with due approval by the Kenya Wildlife Service. The animals were trapped in two batches of five animals each. The morphometric study was conducted only in animals in the second batch. After trapping, the animals were immediately anaesthetized in a chamber using diethyl ether. The ventral abdominal wall was then opened and the abdominal viscera deflected to expose the testes, kidneys (together with their blood vessels) and the caudal vena cavae. Subsequently, the arrangement of the testicular and renal blood vessels as well as caudal vena cavae was carefully examined in situ and the images captured using a digital camera. Thereafter, the animal was perfused using $2.5 \%$ glutaraldehyde delivered through a canulated left ventricle. The perfusate was drained through a slit made on the right atrium. Subsequently, the testes, kidneys, aorta and caudal vena cavae were dissected out for a detailed scrutiny of the vascular pattern and its relationship to the testes and kidneys. The organs were then immersed on the same fixative then transported to the laboratory in the Department of Veterinary Anatomy and Physiology, University of Nairobi. Animals in the second batch were transported live to the lab where weighing, anaesthesia and sample taking were done.

\subsection{Tissue processing}

For microscopic studies (histology and electron microscopy), the testis was cut into eight slices of approximately equal thickness from which two were randomly selected and further cut into four (quarter slices). One quarter slice was selected from each slice and trimmed into a smaller piece of approximately $\mathrm{lmm}^{3}$ (tissue block). For morphometric analysis, the reference volume of testis was first determined using water displacement method (SCHERLE，1970; MANDARIM-DE-LACERDA, 2003; MAKANYA, WARUI and KARLSON., 2004) then the right testis was cut into eight slices of approximately equal thickness from which three were randomly selected. Each slice was further cut into four (quarter slices) one of which was selected from each slice.

The selected tissue blocks and quarter slices were rinsed in $0.1 \mathrm{M}$ phosphate buffer, post-fixed in $1 \%$ osmium tetroxide, dehydrated in ascending concentration of ethanol, cleared with propylene oxide and then embedded in resin. The embedded tissue blocks and quarter slices were sectioned using glass knives to obtain semi-thin and ultrathin sections from the tissue blocks and only semi-thin sections from the quarter slices. Semi-thin sections were stained with toluidine blue then examined under a Leica DM 500 light microscope with a Leica ICC 50 digital camera (Leica Microsystems, Wetzler, Germany) connected to a computer. Ultrathin sections were mounted on copper grids, stained with uranyl acetate then counterstained with lead citrate and viewed under a Phillips 200 transmission electron microscope.

\subsection{Morphometry}

Morphometric analysis was done following Delesse principle (see WEIBEL, KISTLER and SCHERLE, 1966). In brief, toluidine-stained semi-thin sections obtained from the selected resin embedded quarter slices were selected at random. From each of the sections, two fields, randomly selected at $\times 400$ magnification were photographed and the images saved in jpeg format. Twelve such fields were captured from each animal. Each of the digitized section was opened using adobe photoshop ${ }^{\circledR}$ computer software and a grid made up of $5 \mathrm{~mm}$ squares was generated and superimposed on the displayed section. The volume density of various testicular compartments was determined using point counting method with the intersections between grid lines serving as points. At least 7500 points were scored for each animal and categorized either as those falling on the seminiferous tubule, interstitial tissue or the tunica albuginea. The volume density of a compartment was derived from the proportion of points falling on that particular compartment out of a sum of all points falling on the entire section. The points falling on the interstitial tissue were further categorized either as those hitting the blood vessels or other interstitial tissue components. The volume of each compartment was determined as a product of its volume density and testis volume. Since testicular density is estimated at about 1 in mammals (JOHNSON and NEAVES; 1981; MELO, SOUSA, COSTA et al., 2013), the weight of the testis and that of its various compartments was considered equal to the corresponding volumes. The diameter of seminiferous tubules was measured at 200x magnification using an ocular micrometer calibrated with a stage micrometer. At least 20 tubular profiles that were round or nearly round were chosen randomly and measured for each animal. The length of seminiferous tubules was estimated using the formula used in recent publications (CALDEIRA, PAULA, MATTA et al., 2010; CORDEIRO-JÚNIOR, COSTA, TALAMONI et al., 2010; MELO, SOUSA, COSTA et al., 2013).

\subsection{Statistics}

All statistical analyses were performed using sigma plot 12.0 (Systat Software, Inc. SigmaPlot for Windows). The volumes of the left and right testes were compared using student t-test. The estimated values for the volume and volume density of various testicular compartments in different animals were compared using one-way ANOVA. All 
data was presented as mean \pm SEM. $P<0.05$ was considered significant.

\section{Results}

\subsection{Macroscopic examination}

\subsubsection{The testis}

The animals for this study were adults weighing on average $41.8 \pm 1.49 \mathrm{~g}$. The testes were located caudolateral to the kidney, with their cranial poles positioned dorsolaterally to the caudal pole of the kidney (Figure la). They were roughly cylindrical in shape, their long axes oriented cranio-caudally and each had caput epididymis attached along the entire dorsolateral surface.

\subsubsection{The testicular blood vessels}

The testicular arteries branched off, almost perpendicularly, from the renal arteries (Figures $\mathrm{lb}$ and c). Each testicular artery followed a straight course in a caudolateral direction to the respective testis into which it entered midway along the medial border. The arteries did not exhibit any convolutions or close association with any vein.
The testicular veins also followed a straight course and, immediately after exiting from the testes, each received two tributaries; one from the cranial and the other from the caudal direction (see Figures la, d and e). The cranial branch drained blood from the caput epididymis while the caudal one originated from the corpus epididymis. After receiving these epididymal veins, each testicular vein ran straight to the ipsilateral caudal vena cava without forming a pampiniform plexus or showing any intimate association with the testicular arteries.

\subsubsection{The caudal vena cavae}

Caudal to the kidneys, there were separate right and left caudal vena cavae, each receiving ipsilateral testicular and renal veins (see Figures la, d and e). After receiving the renal vein, the left caudal vena cava crossed to the opposite side to join the right one forming the common caudal vena cava, which then extended cranially to eventually drain into the right atrium.

\subsubsection{Microscopic structure}

The testicular parenchyma, bound by tunica albuginea, was predominated by seminiferous tubules interspersed with the interstitial tissue that generally occurred at the angles
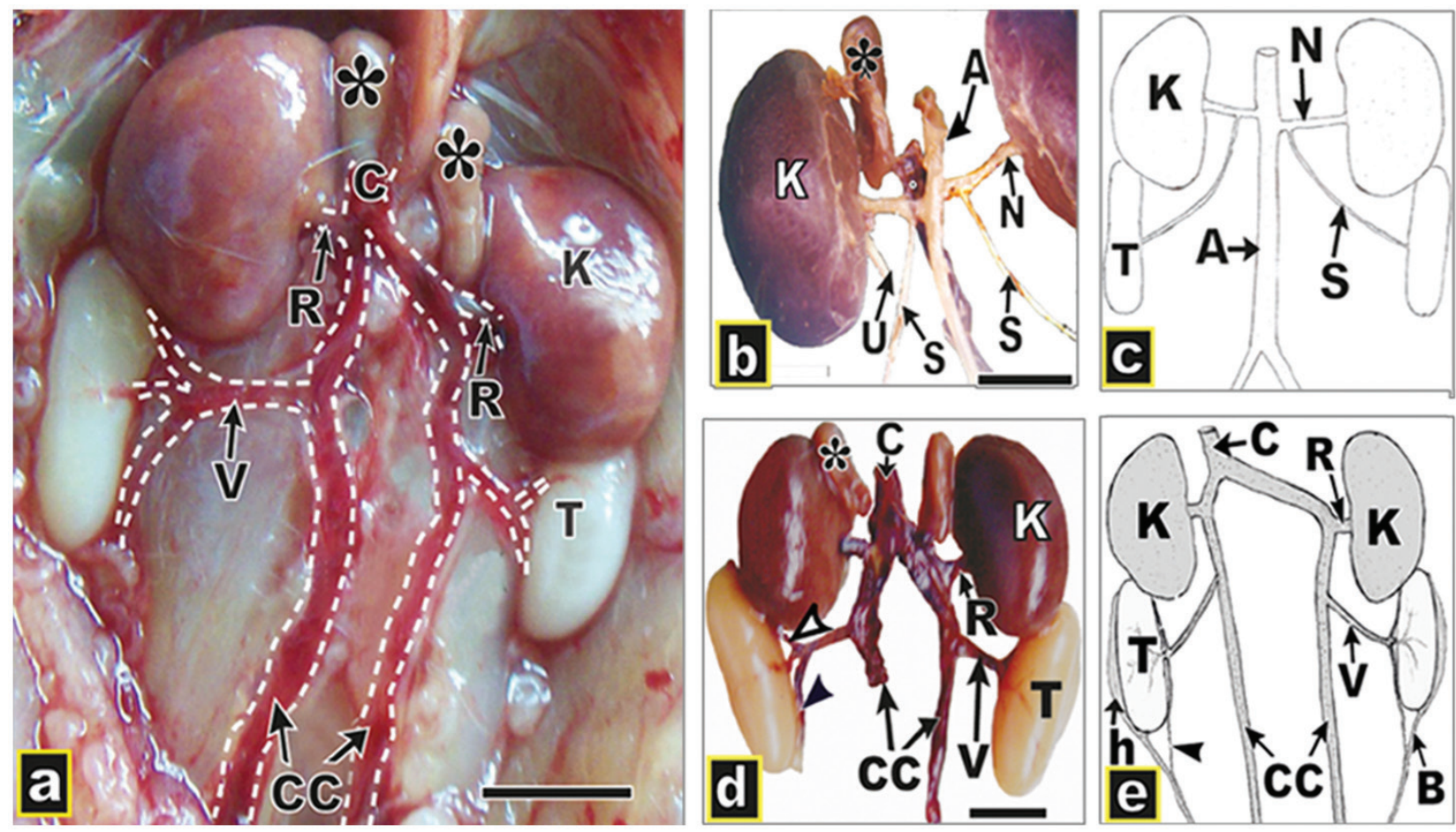

Figure 1. Photographs showing position of testis, the pattern of testicular vessels and caudal vena cava in the rufous sengi. a: Opened abdominal cavity showing the caudo-lateral position of the testis $(\mathbf{T})$ in relation to the kidney $(\mathbf{K})$ and the in situ organization of the paired caudal vena cava $(\mathbf{C C})$, each receiving ipsilateral testicular $(\mathbf{V})$ and renal $(\mathbf{R})$ veins. Asterisks $=$ adrenal glands; $\mathbf{C}=\mathrm{Common}$ caudal vena cava. b: The pattern of testicular arteries $(\mathbf{S})$ branching off from the ipsilateral renal artery $(\mathbf{N})$, which in turn branched off from the abdominal aorta (A). Notice the left adrenal gland (asterisk) lying cranio-medial to the kidney (K) and a stump of the ureter $(\mathbf{U})$ from the same kidney. c: A schematic representation of the course of testicular arteries (S), each branching off from the ipsilateral renal artery $(\mathbf{N})$ then runs straight to the respective testis $(\mathbf{T})$. The renal arteries in turn branch off from the abdominal aorta (A). $\mathbf{d}$ and e: A photograph and a schematic diagram showing paired caudal vena cavae (CC) of rufous sengi, each receiving ipsilateral testicular vein $(\mathbf{V})$ and renal vein $(\mathbf{R})$. Upon receiving the renal vein, the left caudal vena cava crossed to the opposite side to join the right one forming a common caudal vena cava $(\mathbf{C})$. The tributaries of the testicular vein; one (open arrowhead) from the caput epididymis $(\mathbf{h})$ and the other (closed arrowhead) from the corpus epididymis $(\mathbf{B})$, are shown. Asterisk = adrenal gland; $\mathbf{K}=$ kidney; $\mathbf{T}=$ testis. Bars $=5 \mathrm{~mm}$. 
where three or four seminiferous tubules approximated each other, with thin strips extending into narrower spaces between two adjoining tubules (Figure 2a). Interstitial tissue also occurred beneath the tunica albuginea, distributed in spaces/angles formed between peripheral tubules and tunica albuginea (Figure 2b).The seminiferous epithelium comprised of spermatogenic cells at various stages of spermatogenesis. Spermatogonia occurred at the base of the epithelium while advanced spermatogenic cells were located further away from the base (Figures $2 \mathrm{c}$ and $\mathrm{d}$ ), all supported by Sertoli cells (Figure 3a). The Sertoli cell appeared rather tall, spannning the entire thickness of the epithelium with lateral ramifications enveloping spermatogenic cells. Its nucleus, mainly located towards the base, had several deep indentations (Figure 3b). Type A spermatogonia, resting on the basal lamina, had their long axes running parallel to the tubular wall while advanced stages of spermatogenic cells, generally exhibiting interconnections via cytoplasmic bridges (Figure 3c), were located further away from the base. Cap phase spermatids showed profiles of rough endoplasmic reticulum aggregated towards the caudal pole close to the developing tail and peripheral mitochondria distributed towards the anterior pole (see Figure $3 \mathrm{c}$ ). The seminiferous tubules were bound externally by peritubular tissue with a single layer of myoid cells. The myoid cells were elongate and ran parallel to the tubular wall (Figures $3 \mathrm{~b}$ and $\mathrm{d}$ ).

The Leydig cells were closely packed and appeared to, more-or-less, fill the inter-tubular spaces interspersed with blood vessels. They were generally polyhedral in shape with a cytoplasm characterized by abundant lipid droplets (Figure $3 \mathrm{e}$ ). In the interstitial tissue extending into narrow spaces between two adjoining seminiferous tubules, the Leydig cells appeared elongate with rod shaped nuclei (see Figure 3d).

\subsubsection{Morphometry}

Biometric data of rufous sengi (E. rufescens) and various testicular morphometric parameters are shown in Table 1. Comparative seminiferous tubule parameters for rufous sengi (E. rufescens) and a few other mammals are shown in
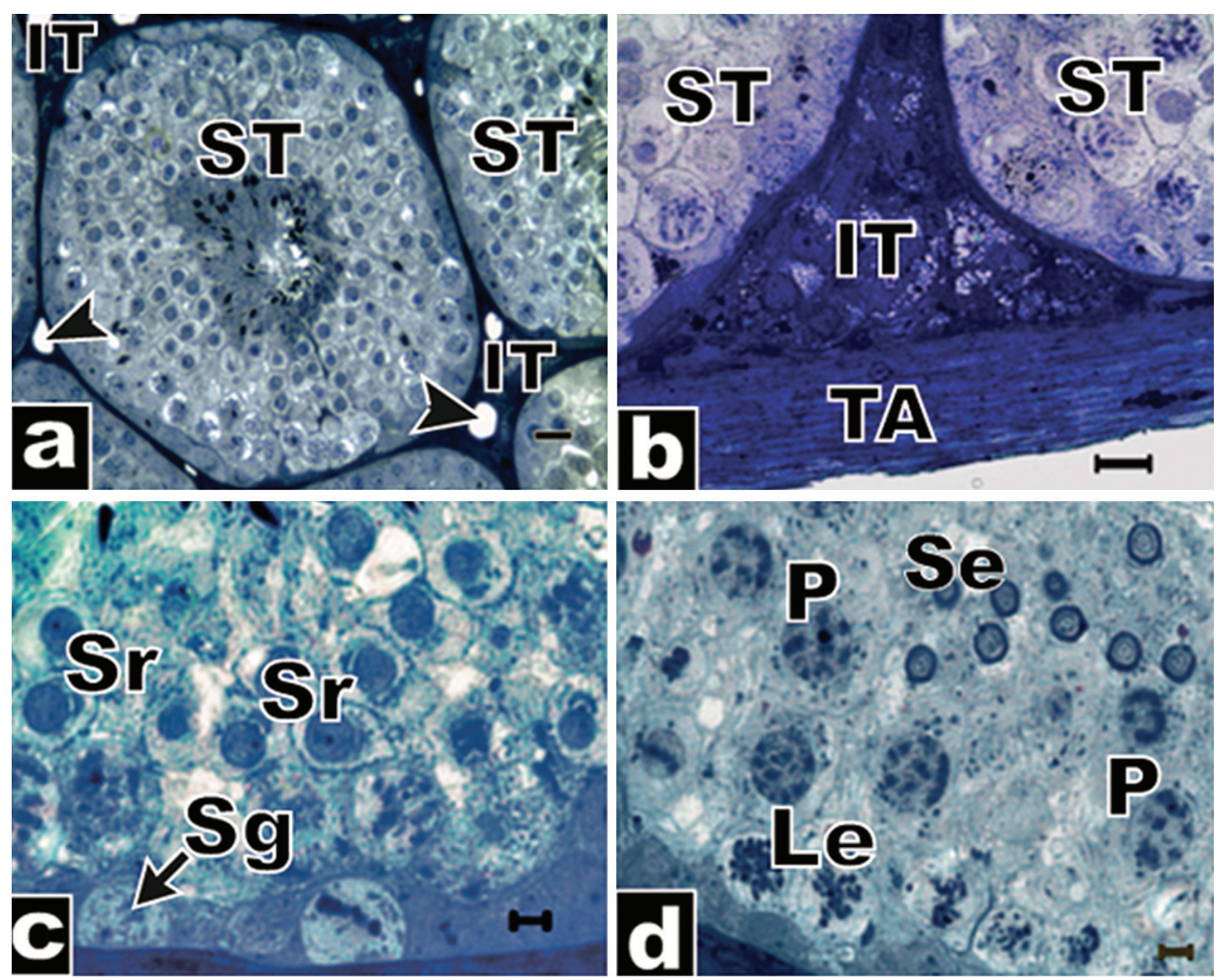

Figure 2. Photomicrographs of testicular parenchyma. a: Seminiferous tubules (ST) are the most predominant components of the parenchyma and are interspersed with relatively scanty interstitial tissue (IT). Notice the blood vessels (arrowheads) in the interstitial tissue. b: The parenchyma is bound by tunica albuginea (TA). Notice the interstitial tissue (IT) with Leydig cells occuring beneath tunica albuginea. Portions of seminiferous tubules (ST) are also shown. c: A portion of the seminiferous epithelium showing spermatogonia $(\mathbf{S g})$ and round spermatids $(\mathbf{S r})$. d: A portion of the seminiferous epithelium showing leptotene spermatocytes $(\mathbf{L e})$, Patchytene spermatocytes $(\mathbf{P})$ and elongating spermatids $(\mathbf{S e})$. Toluidine blue. Bars: $\mathbf{a}$ and $\mathbf{d}=10 \mu \mathrm{m} ; \mathbf{b}$ and $\mathbf{c}=5 \mu \mathrm{m}$. 
Tables 2 and 3 . The mean testicular volume was estimated at $0.089 \pm 0.0031$ (Table 1 ) with the volumes for left and right testes being similar. The seminiferous tubules had a mean diameter of $210 \pm 5.7 \mu \mathrm{m}$ and occupied $89.4 \pm 0.8 \%$ of the testis volume, translating into a volume of approximately
$0.079 \pm 0.0028 \mathrm{~cm}^{3}$ which significantly correlated to the mean testicular volume $(\mathrm{r}=0.966, \mathrm{p}<0.05)$. The tubule length was estimated at $2.27 \pm 0.09$ metres for each testis translating to $28.9 \pm 1.54$ metres per $\mathrm{cm}^{3}$ of testis (Table 2 ). In relation to the body mass, there was $0.0038 \mathrm{~cm}^{3}$ of the
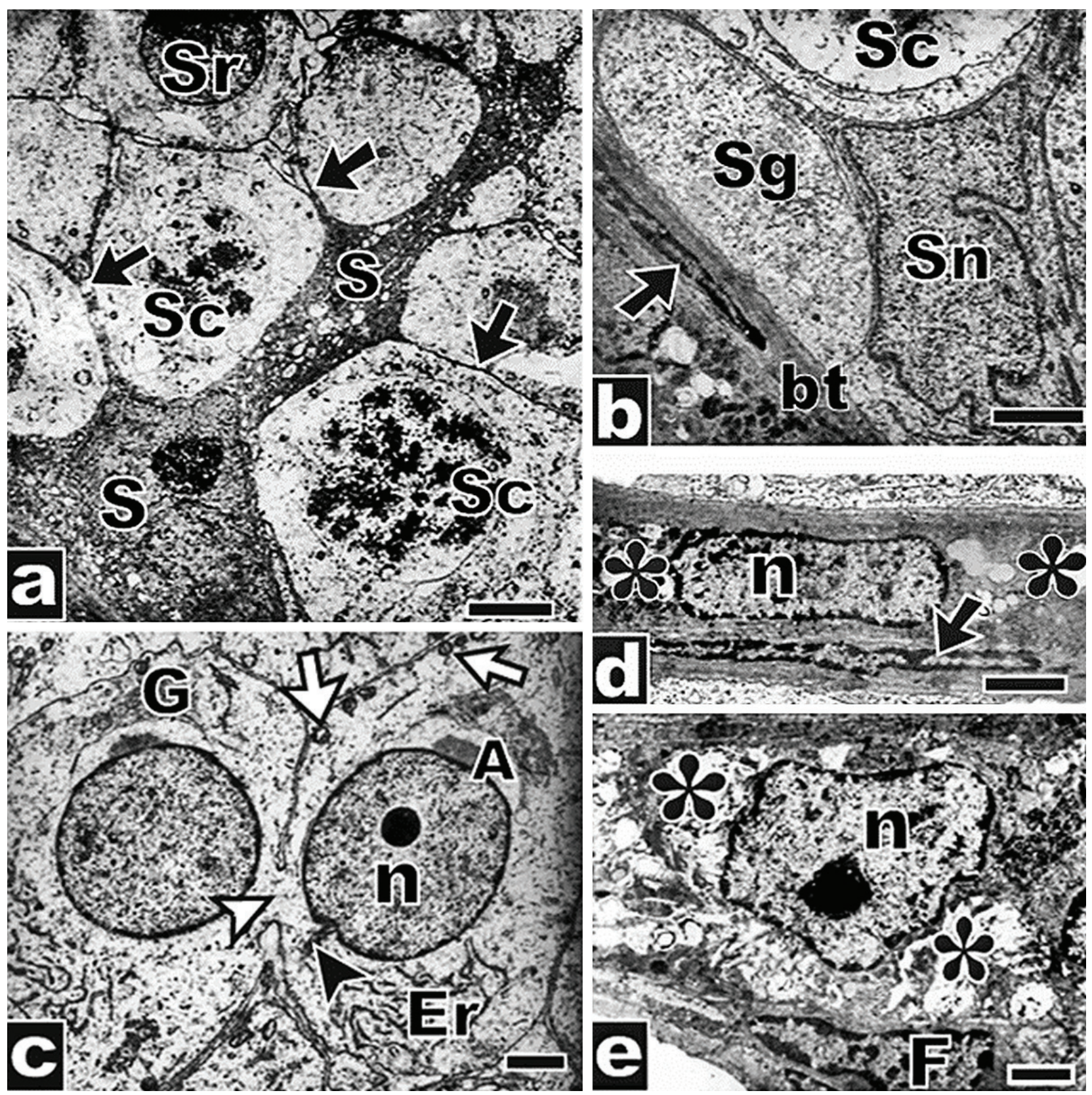

Figure 3. Electron micrographs showing various components of testicular parenchyma. a: A tall Sertoli cell (S) with several ramifications (arrows) enveloping the spermatogenic cells. The spermatogenic cells shown are at various stages of development, and include spermatocytes $(\mathbf{S C})$ and round spermatids $(\mathbf{S r})$. b: Sertoli cell nucleus $(\mathbf{S N})$ with several deep indentations and a type A spermatogonium $(\mathbf{S g})$ which is rather elongate with its long axis running parallel to the tubular wall constituted by the boundary tissue (bt) with a single layer of myoid cells (arrow). A primary spermatocyte (SC) is also shown. c: Two cap phase spermatids joined by a cytoplasmic bridge (open arrowhead). The fragments of rough endoplasmic reticulum (ER) aggregate towards the caudal pole, close to the developing tail (closed arrowhead) while the mitochondria (open arrows) are located towards the anterior pole, arranged along the cell membrane. The nucleus $(\mathbf{N})$ has a prominent nucleolus and it is capped anteriorly by the developing acrosome $(\mathbf{A})$. Notice the Golgi apparatus $(\mathbf{G})$ associated with the developing acrosome. $\mathbf{d}$ : A Leydig cell $(\mathbf{L})$ interposed between two adjacent seminiferous tubules. This cell is long and narrow with elongated cylindrical nucleus ( $\mathbf{N}$ ) and cytoplasm containing lipid droplets (asterisks). A myoid cell (arrow) is also shown. e: A Leydig cell with an irregularly shaped nucleus (N) containing a prominent nucleolus and a cytoplasm with several lipid droplets (asterisks). Notice a fibroblast $(\mathbf{F})$ and a blood vessel (V). Bars: a, $\mathrm{b}$ and $\mathbf{d}=0.5 \mu \mathrm{m} ; \mathrm{c}$ and $\mathrm{e}=0.3 \mu \mathrm{m}$. 
total volume of seminiferous tubule per gram body weight. Since the volume of seminiferous tubules can be used as an estimate of its weight (MELO, SOUSA, COSTA et al., $2013)$, this value was used to obtain the tubulosomatic index $(0.38 \pm 0.3 \%)$ (Table 3$)$. The interstitial tissue occupied $8.9 \pm 0.81 \%$ of the testis which translated into a volume of $0.0079 \pm 0.00083 \mathrm{~cm}^{3}$. Out of the interstitial tissue volume, $9 \%$ was occupied by the blood vessels.

\section{Discussion}

Mammalian testes develop in the abdominal cavity in a cranial position relative to the kidneys (MOORE and PERSAUD, 2003) but descend, in a majority of mammals, to the scrotum. In the elephant, the testes are located caudo-medial to the kidneys (SHORT, MANN and HAY, 1967) while in the sengi and rock hyrax, they are situated caudo-lateral to the kidneys (GLOVER and SALE, 1968; WOODALL, 1995).

The testicular blood supply plays an important role in the mammalian testicular thermoregulation through arteriovenous counter-current heat exchangers that cool the arterial blood to the testes. In scrotal mammals, such a countercurrent heat exchanger is formed along the spermatic cord by the close association between the highly convoluted and branched testicular artery and the pampiniform plexus of the testicular vein (SETCHEL, 1991; DYCE, SACK and WENSING, 2002). In cetaceans, the arterial blood is cooled by the arterio-venous counter-current heat exchanger formed by the juxtaposition between the testicular arterial plexus and the subcutaneous vein from the peripheral surface of the dorsal fin and flukes (ROMMEL, PABST, McLELLAN et al., 1991, 1994; PABST, ROMMEL, MCLELLAN et al., 1995). In the phocid seals however, the testes are cooled, not through the cooling of testicular arterial blood but by the venous plexuses lining the inguinal region, pelvic and abdominal cavities which receive cooled venous blood from hind flippers (BLIX, FAY and RONALD, 1983; ROMMEL, EARLY, MATASSA et al., 1995). In the sengi and other afrotherians, testicular vessels exhibit a simple pattern without any sign of intimate association between the testicular arteries and testicular or any other veins, indicating that these vessels play no role in testicular thermoregulation (SHORT, MANN and HAY, 1967; GLOVER and SALE,

Table 1. Biometric and testicular morphometric data of the rufous sengi.

\begin{tabular}{lcc}
\hline \multicolumn{1}{c}{ Parameter } & Mean \pm SEM \\
\hline Body mass $(\mathrm{g})$ & & $41.8 \pm 1.49$ \\
Testicular volume $\left(\mathrm{cm}^{3}\right)$ & & $0.089 \pm 0.0031$ \\
Seminiferous tubule: & Diameter $(\mu \mathrm{m})$ & $210 \pm 5.7$ \\
& Volume density $(\%)$ & $89.4 \pm 0.008$ \\
& Volume per testis $\left(\mathrm{cm}^{3}\right)$ & $0.079 \pm 0.003$ \\
& Length per testis $(\mathrm{m})$ & $2.27 \pm 0.09$ \\
Interstitial tissue: & Length per cm $\mathrm{cm}^{3}$ of testis $(\mathrm{m})$ & $28.9 \pm 1.54$ \\
& Volume density $(\%)$ & $8.9 \pm 0.008$ \\
\hline
\end{tabular}

Table 2. Comparative parameters related to the length of seminiferous tubules in the rufous sengi and a few select species.

\begin{tabular}{lccl}
\hline \multicolumn{1}{c}{ Species } & \multicolumn{2}{c}{ Tubule length (meters) } & \\
\cline { 2 - 3 } & per testis & $\begin{array}{c}\text { per gram } \\
\text { of testis }\end{array}$ & Reference \\
\hline Rufous sengi (E. rufescens) & 2.27 & 28.9 & Current study \\
Large-headed rice rat (Hylaeamis & 2.53 & 27.96 & Melo, Sousa, Costa et al. (2013) \\
megacephalus) & 38 & 39 & Cordeiro-Júnior, Costa, Talamoni et al. (2010) \\
Spiny rat (Trinomys moojeni) & 710 & 21.5 & Costa, Matta, Gomes et al. (2011) \\
brown brocket deer (Mazama gouazoubira) & 1829 & 20 & Leal, Becke-Silva, Chiarini-Garcia et al. (2004) \\
Goat (Capra hircus) & 1022 & 18.3 & Almeida, Leal and Franca (2006) \\
Wild boar (Sus scrofa scrofa) & 150 & 16.7 & Silva, Costa, Andrade et al. (2010) \\
Ocelot (Leopardus pardalis) & 22.8 & 23.1 & França and Godinho (2003) \\
Domestic cat (Felis catus) & & &
\end{tabular}

Table 3. Comparative tubulosomatic indices (TSI) in the rufous sengi, large-headed rice rat, crab-eating fox and brown brocket deer.

\begin{tabular}{lccl}
\hline \multicolumn{1}{c}{ Species } & $\begin{array}{c}\text { Body weight } \\
(\mathbf{g})\end{array}$ & $\begin{array}{c}\text { TSI } \\
\mathbf{( \% )}\end{array}$ & \multicolumn{1}{c}{ Reference } \\
\hline Rufous sengi (E. rufescens) & 41.8 & 0.38 & Current study \\
Large-headed rice rat (Hylaeamis megacephalus) & 47.84 & 0.36 & Melo, Sousa, Costa et al. (2013) \\
Crab-eating fox (Cerdocyon thous) & 6530 & 0.042 & Caldeira, Paula, Matta et al. (2010) \\
brown brocket deer (Mazama gouazoubira) & 17200 & 0.33 & Costa, Matta, Gomes et al. (2011) \\
\hline
\end{tabular}


1968; ROMMEL, PABST and McLELLAN, 2001). This confirms that there is no cooling of arterial blood to the testes of primary testicondids and on the basis of their location, it is justifiable to assume that their testes are adapted to function at core body temperature (WERDELIN and NILSONNE, 1999). Since afrotheria is the most basal clade on the phylogenetic tree of placental mammals (KLEISNER, IVELL and FLEGR, 2010), it is probable that this pattern, together with the intra-abdominal position of the testes, represents the ancestral eutherian state.

The pattern of caudal vena cava in the sengi, where it is double caudal to the kidneys, is similar to what has been reported in the manatee; a member of the super order afrotheria (ROMMEL and CAPLAN, 2003). This feature is most probably a result of the persistence of the post renal portion of the left supracardinal vein which usually disappears in other mammals (WALKER and LIEM, 1994; MOORE and PERSAUD, 2003), while the segment that crosses to the right side to connect the left caudal vena cava to the right one is most probably derived from the left sub-supracardinal anastomosis. The common caudal vena cava, as it applies in sengi, likely corresponds to the segment derived from the right subcardinal and the right hepatic veins. Incidental double caudal vena cava has also been reported in other mammals as an aberration (EVANS, 1993; MOORE and PERSAUD, 2003; CORNILLIE and SIMEONS, 2005).

The microscopic structure of sengi's testis reflects the general mammalian features, exhibiting complete spermatogenesis in spite of its intra-abdiominal location. Sertoli cell is a tall pyramidal cell that spans the entire thickness of the seminiferous epithelium, with several lateral extensions that envelope several spermatogenic cells. This study has similarly demonstrated Such an outline of Sertoli cell and serves as a good structural indicator of the importance of this cell in coordination of spermatogenesis, protection and support (physical and metabolic) of the germ cells, besides the role in maintenance of the structural integrity of the seminiferous epithelium (COUROT, REVIERS and ORTAVANT, 1970; BARDIN, GUNSALUS and CHENG, 1993).

The organization of sengi's spermatogenic cells was in conformity with what is generally found in mammals, where spermatogonia are confined to the basal compartment of the seminiferous epithelium and rest on the basal lamina while the successive stages are displaced to various epithelial levels away from the base (RUSSELL, ETTLIN, HIKIM et al., 1990). Spermatocytes arise after several mitotic divisions of spermatogonia and in turn undergo meiotic divisions to give rise to spermatids. The spermatid is a haploid cell that undergoes several stages of differentiation (spermiogenesis) to give rise to a mature spermatozoon. The events leading to this transformation were demonstrated in this study, and included reorganization of cell components to form specialized structures such as the acrosome and flagellum. The displacement of rough endoplasmic reticulum fragments to the caudal pole and mitochondria towards the cranial pole in cap phase spermatids is likely an indication of reorganization and segregation of cellular structures such that those destined to be rid of in cytoplasmic droplets are displaced caudally while those to be preserved, mainly the mitochondria, are at this stage segregated towards the cranial pole. The seminiferous tubules are enveloped by the peritubular boundary tissue that contains myoid cells occurring in one or more layers depending on the species (MAEKAWA, KAMIMURA and NAGANO, 1996; AIRE and OZEGBE, 2007). In the rufous sengi, boundary tissue contained a single layer of myoid cells, similar to what has been reported in rats, mice and hamsters (MAEKAWA, KAMIMURA and NAGANO, 1996).

Mammalian Leydig cells are generally polyhedral with spherical to ovoid nuclei and, since they are involved in steroid biosynthesis, their cytoplasm is characterized by abundance of mitochondria and presence of lipid droplets (EURELL and FRAPPIER, 2006). In the rufous sengi, Leydig cells were also polyhedral with irregular nuclei and their cytoplasm had numerous lipid droplets serving as one of the indirect indicators of their role in biosynthesis of steroid hormones. The Leydig cells found in narrow spaces between two adjoining seminiferous tubules were elongate with rod shaped nuclei. On this structural basis, it is plausible to suggest that besides their polyhedral shape, Leydig cells can vary their shape and that of their nuclei to conform and fit into available space.

The organization and quantities of various components of testicular parenchyma show variations between mammalian species (FAWCETT, NEAVES and FLORES, 1973). In the rufous sengi, seminiferous tubules contributed more than $89 \%$ of the testicular volume with the interstitial tissue representing less than $9 \%$. The proportion of testis volume occupied by the seminiferous tubules, like that reported in the domestic cat and goat, is in the upper level compared with other mammals studied (FRANÇA and GODINHO, 2003; LEAL, BECKE-SILVA, CHIARINI-GARCIA et al., 2004). The results therefore confirm the earlier reports, with backing from quantitative analysis using stereology, that sengis have little interstitial tissue (ASDELL, 1964).

Seminiferous tubules constitute a testicular component directly involved in spermatogenesis. Its measurements have therefore been used as one of the indicators of spermatogenic activity (MELO, SOUSA, COSTA et al., 2013). The mean diameter of seminiferous tubule in the rufous sengi (E. rufescens) fell within the range observed in mammals studied (LEAL, BECKE-SILVA, CHIARINIGARCIA et al., 2004; CALDEIRA, PAULA, MATTA et al., 2010; COSTA, MATTA, GOMES et al., 2011; MELO, SOUSA, COSTA et al., 2013) while its estimated total length of 4.54 in both testes is close to that reported in Hyalaeamys megacephalus, a mammal of almost the same size, (MELO, SOUSA, COSTA et al., 2013). To make the estimate on total tubule length independent of body size, this parameter is converted to length per gram of testis (MELO, SOUSA, COSTA et al., 2013). In our study, the conversion was reported as length per unit volume (in $\mathrm{cm}^{3}$ ) of testis so as to indicate the amount in length, of the spermatogenic tissue, contained within a unit amount of space provided by the testis (although the value will be the same as that of length per gram of testis bearing in mind that the volume of the mammalian testis is approximately equal to its weight). Thus, rufous sengi presented $28.9 \pm 1.5$ meters per cubic centimeters of testis which, when expressed as meters per gram of testis, is higher than that reported in a number of carnivores (CALDEIRA, PAULA, MATTA et al., 2010; SILVA, COSTA, ANDRADE et al., 2010), wild boar (ALMEIDA, LEAL and FRANCA, 2006), the goat (LEAL, 
BECKE-SILVA, CHIARINI-GARCIA et al., 2004) and the brown brocket deer (COSTA, MATTA, GOMES et al., 2011) but similar to that reported in large-headed rice rat, Hyalaeamys megacephalus (MELO, SOUSA, COSTA et al., 2013). Some studies indicate that this parameter is directly proportional to sperm production (MACHADO JUNIOR, ASSIS NETO, SOUSA JUNIOR et al., 2011) and in this regard, it is apparent that sengis and rodents have high sperm production as compared to several other mammalian groups (see Table 2), although more comparative data is required to support this statement.

Gonadosomatic index quantifies investment in gonads relative to body mass and is a useful reproductive indicator (MELO, SOUSA, COSTA et al., 2013). Since seminiferous tubules forms the compartment that is directly involved in spermatogenesis and its proportion in the testis may vary between species, it might be more appropriate to use tubulosomatic index, which quantifies investment in this compartment relative to body mass, as an indicator of relative spermatogenic activity (CALDEIRA, PAULA, MATTA et al., 2010; MELO, SOUSA, COSTA et al., 2013). The Tubulosomatic index of $0.38 \%$ observed in the rufous sengi is high and falls within the range observed in promiscuous animals (MELO, SOUSA, COSTA et al., 2013). Although greater investment of body mass to seminiferous tubules may be expected in smaller animals such as rufous sengi compared to larger ones, such a high tubulosomatic index was not expected in this animal given earlier reports on behaviour that have established sengis as monogamous animals (RATHBUN and RATHBUN, 2006). This result could be taken to mean that this species of sengi may be facultatively monogamous and may exhibit polygamy as has been reported in bushveld sengi, Elephantulus intufi (RATHBUN and RATHBUN, 2006). This explanation alone may not be adequate to justify such a high tubulosomatic index that is even higher than that of established promiscuous animals such as Hyalaeamys megacephalus (MELO, SOUSA, COSTA et al., 2013). It could be postulated that such a high indicator of spermatogenic activity is an adaptive strategy of testicondid mammals to increase chances of producing viable spermatozoa given that their testes are located in a rather 'hostile' intra-abdominal environment. More studies are however needed in sengis and other testicondid mammals to verify this.

\section{Conclusion}

In general, the structure of sengi's testis conform to the general feature in mammals but the pattern of testicular vessels do not since they are straight and unspecialized without thermoregulatory role, reflecting what has been reported in other afrotherian mammals. Being basal eutherian clade, the location of testes and the simple pattern of testicular vessels in afrotherians possibly reflect the ancestral eutherian state. The morphometric data also generally agrees with earlier reports that sengi testis have less interstitial tissue. In this report, however, such a conclusion is backed by quantitative analyses. The seminiferous tubule parameters such as tubulosomatic index suggest a very high spermatogenic activity than expected in such an animal established as being monogamous. The double caudal vena cava is most likely a result of retention of the left post-renal segment of the supracardinal and left sub-supracardinal anastomosis.

\section{Acknowledgements}

This study was supported by the grant from the Deans Committee of the University of Nairobi. We wish to thank the Kenya Wildlife Service for the assistance in locating and trapping of the animals and Mr. Ben Agwanda of mammalogy section of the National Museums of Kenya for species diagnosis and assistance in trapping. We also thank Mr. Jackson Gachoka of the Department of Veterinary Pathology, Microbiology and Parasitology, University of Nairobi, for his assistance in electron microscopy work.The authors declare that they have no conflict of interest.

\section{References}

AIRE, TA. and OZEGBE, PC. The testicular capsule and peritubular tissue of birds: morphometry, histology, ultrastructure and immunohistochemistry. Journal of Anatomy, 2007, vol. 210, n. 6, p. 731-740. PMid:17451470 PMCid:PMC2375754. http:// dx.doi.org/10.1111/j.1469-7580.2007.00726.x

ALMEIDA, FFL., LEAL, MC. and FRANÇA, LR. Testis morphometry, duration of spermatogenesis, and spermatogenic efficiency in the wild boar (Sus scrofa scrofa). Biology of Reproduction, 2006, vol. 75 , n. 5, p. 792-799. PMid:16870941. http://dx.doi. org/10.1095/biolreprod.106.053835

ARNASON, U., ADEGOKE, JA., BODIN, K., BORN, EW., ESA, YB., GULLBERG, A., NILSSON, M., SHORT, RV., XU, X. and JANKE, A. 2002. Mammalian mitogenomic relationships and the root of the eutherian tree. Proceedings of the National Academy of Sciences, 2002, vol. 99, n. 12, p. 8151-8156. PMid:12034869 PMCid:PMC123036. http://dx.doi.org/10.1073/pnas.102164299

ASDELL, SA. Patterns of mammalian reproduction. New York: Comstock Publishing Associates, 1964. 670 p.

BARDIN, WC., GUNSALUS, GL. and CHENG, CY. The cell biology of the Sertoli cell. In DESJARDINS, C. and EWING, LL. Cell and molecular biology of the testis. New York: Oxford University Press, 1993. p. 189-219.

BLIX, AS., FAY, FH. and RONALD, K. On testicular cooling in phocid seals. Polar Research, 1983, vol. 1, n. 3, p. 231-234. http:// dx.doi.org/10.1111/j.1751-8369.1983.tb00738.x

BUDRAS, K., McCARTHY, PH., FRICKE, W. and RICHTER, R. Anatomy of the dog. Hannover: Schlutersche, 2007. 218 p.

CALDEIRA, CB., PAULA, TAR., MATTA, SLP., BALARINI, MK. and CAMPOS, PKA. Morphometry of testis and seminiferous tubules of the adult crab-eating fox (Cerdocyon thous Linnaeus, 1766). Revista Ceres, 2010, vol. 57, n. 5, p. 569-575. http:// dx.doi.org/10.1590/S0034-737X2010000500001

CORDEIRO-JÚNIOR, DA., COSTA, GMJ., TALAMONI, SA. and FRANÇA, LR. Spermatogenic efficiency in the spiny rat trinomys moojeni (Rodentia: Echimyidae). Animal Reproduction Science, 2010, vol. 119, n. 1-2, p. 97-105. PMid:20018466. http://dx.doi.org/10.1016/j.anireprosci.2009.11.006

CORNILLIE, P. and SIMEONS, P. Prenatal development of the caudal vena cava in mammals: Review of the different theories with special reference to the dog. Anatomia Histologia Embryologia, 2005, vol. 34, n. 6, p. 364-372. PMid:16288607. http://dx.doi. org/10.1111/j.1439-0264.2005.00625.x

COSTA, KLC., MATTA, SLP., GOMES, MLM., PAULA, TAR., FREITAS, KM., CARVALHO, FAR., SILVEIRA, JA., DOLDER, $\mathrm{H}$. and MENDIS-HANDAGAMA, SMLC. Histomorphometric evaluation of the neotropical brocket deer Mazama gouazobira 
testis, with an emphasis on cell population indexes of spermatogenic yield. Animal Reproduction Science, 2011, vol. 127, n. 3-4, p. 202-212. PMid:21889273. http://dx.doi.org/10.1016/j. anireprosci.2011.07.016

COUROT, M., REVIERS, HMT. and ORTAVANT, R. Spermatogenesis. In JOHNSON, AD., GOMES, WR. and VANDERMARK, NL. The testis. New York: Academic Press, 1970. p. 339-432. v. 1 .

DYCE, KM., SACK, WO. and WENSING, CJG. Textbook of veterinary anatomy. Philadelphia: Saunders, 2002. 840 p.

EURELL, JA. and FRAPPIER, BL. Dellman's textbook of veterinary histology. Iowa: Blackwell Publishing, 2006. 405 p.

EVANS, HE. Miller's anatomy of the dog. Philadelphia: WB Saunders Company, 1993. 1113 p.

FAWCETT, DW., NEAVES, WB. and FLORES, MN. Comparative observations on intertubular lymphatics and the organization of the interstitial tissue of the mammalian testis. Biology of Reproduction, 1973, vol. 9, n. 5, p. 500-532. PMid:4203289.

FRANÇA, LR. and GODINHO, CL. Testis morphometry, seminiferous epithelium cycle length and daily sperm production in domestic cats (Felis catus). Biology of Reproduction, 2003, vol. 68, n. 5, p. 1554-1561. PMid:12606460.

GLOVER, TD. and SALE, JB. The reproductive system of male rock hyrax (Procavia and Heterobyrax). Journal of Zoology, 1968, vol. 156, n. 3, p. 351-362.

JOHNSON, L. and NEAVES, WB. Age-related changes in Leydig cell population, seminiferous tubules and sperm production in stallions. Biology of Reproduction, 1981, vol. 24, n. 3, p. 703-712. PMid:7236827. http://dx.doi.org/10.1095/biolreprod24.3.703

KINGDON, J. The kingdon field guide to african mammals. San Diego: Academic Press, 2001. 479 p.

KLEISNER, K., IVELL, R. and FLEGR, J. The evolutionary history of testicular externalization and the origin of the scrotum. Journal of Biosciences, 2010, vol. 35, n. 1, p. 1-11. http://dx.doi. org/10.1007/s12038-010-0005-7

LEAL, MC., BECKE-SILVA, SC., CHIARINI-GARCIA, H. and FRANÇA, LR. Sertoli cell efficiency and daily sperm production in goats (Capra hircus). Animal Reproduction Science, 2004, vol. 1, p. 122-128.

MACHADO JUNIOR, AAN., ASSIS NETO, AC., SOUSA JUNIOR, A., MENEZES, DJA., ALVES, FR., SOUSA, AL. and CARVALHO, MAM. Daily sperm production and testicular morphometry in goats according to external scrotal conformation. Animal Reproduction Science, 2011, vol. 127, n. 1-2, p. 73-77. PMid:21802871. http://dx.doi.org/10.1016/j. anireprosci.2011.06.008

MAEKAWA, M., KAMIMURA, K. and NAGANO, T. Peritubular myoid cells in the testis: Their structure and function. Archives of Histology and Cytology, 1996, vol. 59, n. 1, p. 1-13. PMid:8727359. http://dx.doi.org/10.1679/aohc.59.1

MAKANYA, AN., WARUI, CN. and KARLSON, LM. Current stereological methods and tools for simple quantification of biological structures: a short review. Kenya Veterinarian, 2004, vol. 27, p. 113-117.

MANDARIM-DE-LACERDA, CA. Stereological tools in biomedical research. Anais da Academia Brasileira de Ciências, 2003, vol. 75, n. 4, p. 469-486. PMid:14605681.

MELO, FCSA., SOUSA, TP., COSTA, KLC., MATTA, SLP., MELO, FR. and SANTA-RITA, RM. Descriptive morphometry and stereology of the tubular compartment in the wild rodent Hylaeamys megacephalus (rodentia: cricketidae) from central Brazil. Animal
Reproduction Science, 2013, vol. 138, p. 110-117. PMid:23473695. http://dx.doi.org/10.1016/j.anireprosci.2013.01.013

MOORE, KL. and PERSAUD, TVN. The developing human: clinically oriented embryology. Philadelphia: WB Saunders, 2003. $560 \mathrm{p}$.

NOWAK, RM. Walker's mammals of the world. Baltimore: John Hopkins University Press, 1999. 1936 p. v. 2.

ONYANGO, DW., ODUOR-OKELO, D. and OTIANG'AOWITI, GE. Ultrastructural study of the testis of non-breeding naked mole-rat (Heterocephalus glaber, Rupell). Annals of Anatomy, 1993, vol. 175, n. 5, p. 447-452. http://dx.doi.org/10.1016/ S0940-9602(11)80111-1

PABST, DA., ROMMEL, SA., MCLELLAN, WA., WILLIAMS, TM. and ROWLES, TK. Thermoregulation of the intra-abdominal testes of the bottlenose dolphin (Tursiops truncatus) during exercise. Journal of Experimental Biology, 1995, vol. 198, p. 221-226. PMid:7891036.

RATHBUN, GB. and RATHBUN, CD. Social structure of the bushveld sengi (Elephantulus intufi) in Namibia and the evolution of monogamy in the Macroscelidea. Journal of Zoology, 2006, vol. 269 , n. 3, p. 391-399. http://dx.doi.org/10.1111/j.14697998.2006.00087.x

ROMMEL, SA., PABST, DA., MCLELLAN, WA., MEAD, JG. and POTTER, CW. Anatomical evidence for a counter-current heat exchanger associated with dolphin testes. The Anatomic Record, 1991, vol. 232, n. 1, p. 150-156.

ROMMEL, SA., PABST, DA., MCLELLAN, WA, WILLIAMS, TM. and FRIEDL, WA. Temperature regulation of the testis of the bottlenose dolphin (Tursiops truncatus): evidence from colonic temperatures. Journal of Comparative Physiology B, 1994, vol. 164, n. 2, p. 130-134. PMid:8056879. http://dx.doi.org/10.1007/ BF00301654

ROMMEL, SA., EARLY, GA., MATASSA, KA., PABST, DA. and MCLELLAN, WA. Venous structures associated with thermoregulation of phocid seal reproductive organs. The Anatomic Record, 1995, vol. 243, n. 3, p. 390-402. PMid:8579259. http:// dx.doi.org/10.1002/ar.1092430314

ROMMEL, SA., PABST, DA. and MCLELLAN, WA. Functional morphology of venous structures associated with the male and female reproductive systems in Florida manatees (Trichechus manatus latirostris). The Anatomic Record, 2001, vol. 264, n. 4, p. 339-347. PMid:11745089. http://dx.doi.org/10.1002/ar.10022

ROMMEL, SA. and CAPLAN, H. Vascular adaptations for heat conservation in the tail of Florida manatees (Trichechus manatus latirostris). Journal of Anatomy, 2003, vol. 202, n. 4, p. 343353. PMid:12739612 PMCid:PMC1571090. http://dx.doi. org/10.1046/j.1469-7580.2003.00170.x

RUSSELL, LD., ETTLIN, RA., HIKIM, APS. and CLEGG, ED. Histological and histopathological evaluation of the testis. Clearwater: Cache River Press, 1990. 286 p.

SCHERLE, WF. A simple method of volumetry of organs in quantitative stereology. Mikroskopie, 1970, vol. 26, n. 1, p. 57-60. PMid:5530651.

SETCHEL, BP. Male reproductive organs and semen. In CUPPS, PT. Reproduction in domestic animals. San Diego: Academic Press, 1991. p. 221-249.

SETCHEL, BP. and BREED, WG. Anatomy, vasculature, and innervation of the male reproductive tract. In NEILL, JD. Knobil and Neill's physiology of reproduction. St Louis: Academic Press, 2006. p. 771-826. v. 1. http://dx.doi.org/10.1016/B978012515400-0/50022-1 
SHORT, RV., MANN, T. and HAY, MF. Male reproductive organs of the African elephant, Loxodonta africana. Journal of Reproduction and Fertility, 1967, vol. 13, p. 517-536. PMid:6029179. http:// dx.doi.org/10.1530/jrf.0.0130517

SILVA, RC., COSTA, GMJ., ANDRADE, LM. and FRANÇA, LR. Testis stereology, seminiferous epithelium cycle length and daily sperm production in the ocelot (Leopardus pardalis). Theriogenology, 2010, vol. 73, n. 2, p. 157-167. PMid:19853903. http://dx.doi.org/10.1016/j.theriogenology.2009.08.009

SPRINGER, MS., CLEVEN, GC., MADSEN, O., JONG, W., WADDELL, VG., AMRINE, HM. and STANHOPE, MJ. Endemic African mammals shake the phylogenetic tree. Nature, 1997, vol. 388, p. 61-64. PMid:9214502. http://dx.doi. org $/ 10.1038 / 40386$

STOCH, ZG. The male genital system and reproductive cycle of Elephantulus myurus jamesoni (Chubb). Philosophical Transactions of the Royal Society B, 1954, vol. 238, n. 653, p. 99-126. http:// dx.doi.org/10.1098/rstb.1954.0007

VAN DIJK, MAM., MADSEN, O., CATZEFLIS, F., STANHOPE, MJ., DE JONG, WW. and PAGEL, M. Protein sequence signatures support the African clade of mammals. Proceedings of National
Academy of Sciences, 2001, vol. 98, n. 1, p. 188-193. PMid:11114173 PMCid:PMC14566. http://dx.doi.org/10.1073/pnas.98.1.188

WALKER, WF. and LIEM, KF. Functional anatomy of the vertebrates: an evolutionary perspective. Philadelphia: Saunders College Publishing, 1994. 840 p.

WEIBEL, ER., KISTLER, GS. and SCHERLE, WF. Practical stereological methods for morphometric cytology. Journal of Cell Biology, 1966, vol. 30, n. 1, p. 23-38. PMid:5338131 PMCid:PMC2106982. http://dx.doi.org/10.1083/jcb.30.1.23

WERDELIN, L. and NILSONNE, A. The evolution of scrotum and testicular descent in mammals: a phylogenetic view. Journal of Theoretical Biology, 1999, vol. 196, n. 1, p. 61-72. PMid:9892556. http://dx.doi.org/10.1006/jtbi.1998.0821

WOODALL, PF. The male reproductive system and the phylogeny of elephant-shrews (macroscelidea). Mammal Review, 1995, vol. 25, n. 1-2, p. 87-93. http://dx.doi.org/10.1111/j.1365-2907.1995. tb00441.x

Received October 24, 2013 Accepted August 8, 2014 